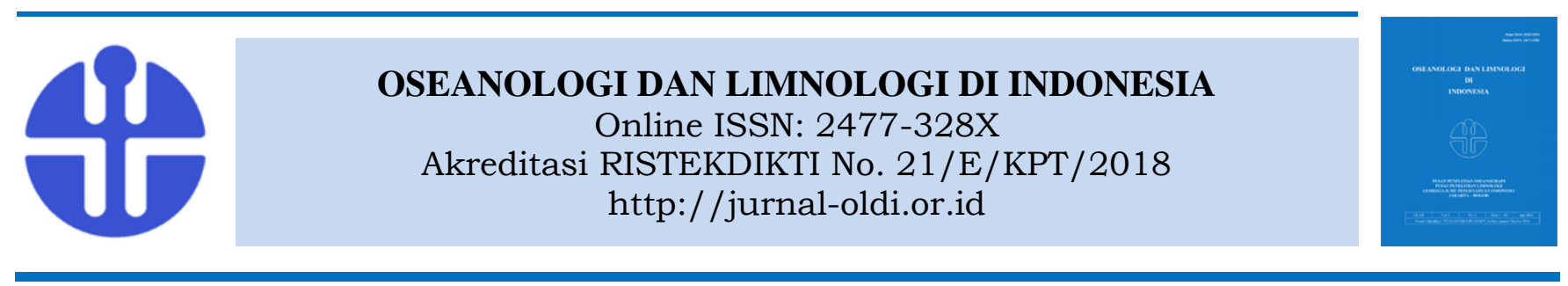

\title{
Karakterisasi Enzim Xilanase dari Isolat Bacillus sp. UJ131 di Hutan Mangrove Margasari Lampung Timur sebagai Kandidat Probiotik
}

\author{
Sumardi $^{1}$, Salman Farisi ${ }^{1}$, Christina Nugroho Ekowati ${ }^{1}$, dan Suminta Frida Hairisah ${ }^{1}$ \\ ${ }^{1}$ Jurusan Biologi FMIPA Universitas Lampung \\ Jl. Prof. Dr. Soemantri Brodjonegoro No. 1 Bandar Lampung 35145 \\ E-mail: sumardi_bio@yahoo.co.id
}

Submitted 7 April 2018. Reviewed 4 May 2018. Accepted 3 September 2019.

DOI: 10.14203/oldi.2019.v4i3.201

\begin{abstract}
Abstrak
Hutan mangrove diketahui memiliki biodiversitas yang tinggi sebagai lokasi yang berpotensi untuk eksplorasi bakteri penghasil enzim, salah satunya enzim xilanase. Xilanase merupakan enzim yang menghidrolisis substrat hemiselulosa kaya xilan. Penelitian ini bertujuan untuk memproduksi dan mengetahui karakter enzim xilanase isolat Bacillus sp. UJ131 yang diisolasi dari udang pasir di hutan mangrove Margasari Lampung Timur. Enzim xilanase diproduksi dari bakteri tersebut dengan menumbuhkan dalam media sea water complete (SWC) cair yang mengandung xylane beechwood. Karakterisasi enzim xilanase meliputi pengaruh $\mathrm{pH}$, suhu, dan ion logam. Hasil penelitian menunjukkan bahwa enzim xilanase ini memiliki waktu optimum 18 jam dengan aktifitas xilanase sebesar $0,18 \mathrm{U} / \mathrm{ml}$, serta bekerja optimum pada pH 6 dan suhu $70^{\circ} \mathrm{C}$. Penambahan ion $\mathrm{Mn}^{4+}$ dan $\mathrm{Ca}^{2+}$ dapat meningkatkan aktivitas enzim, sebaliknya ion $\mathrm{Fe}^{3+}, \mathrm{Cu}^{4+}$ dan $\mathrm{Mg}^{2+}$ menurunkan aktivitas enzim xilanase. Pada kecepatan reaksi maksimal sebesar 0,25 $\mathrm{U} / \mathrm{ml}$, enzim xilanase dapat menghasilkan $1,30 \mu \mathrm{M}$ xilosa per menit.
\end{abstract}

Kata Kunci: Bacillus sp. UJ131, karakterisasi, xilanase.

\begin{abstract}
Characterization of Xilanase Enzyme by Bacillus sp. UJ131 A Probiotic Candidate from the Mangrove of Margasari, East Lampung. Mangrove are known to have high biodiversity as a potential location for exploration of enzyme-producing bacteria, one of which is the xylanase enzyme. Xylanase is an enzyme that hydrolyzes the xylan-rich hemicellulose substrate. This research aims to produce and know the character of xylanase enzyme by Bacillus sp. UJ131 isolate which was isolated from the oriental shrimp in Margasari mangrove forest of East Lampung. Xylanase enzymes are produced from the bacteria by growing them in sea water complete (SWC) broth containing xylan beechwood. Characterization xylanase enzyme consist of $\mathrm{pH}$, temperature, and metal ions. The results showed that xylanase had an optimal time of 18 hours with xylanase activity of $0.18 \mathrm{U} / \mathrm{ml}$, and optimally at $\mathrm{pH} 6$ and temperature $70^{\circ} \mathrm{C}$. The addition of $\mathrm{Mn}^{2+}$ and $\mathrm{Ca}^{2+}$ ions increase enzyme activity, but $\mathrm{Fe}^{3+}, \mathrm{Cu}^{2+}$ and $\mathrm{Mg}^{2+}$ ions decrease xylanase enzyme activity. At a maximum reaction speed of $0.25 \mathrm{U} / \mathrm{ml}$, the xylanase enzyme can produce $1.30 \mu \mathrm{M}$ xylose per minute.
\end{abstract}

Keyword: Bacillus sp. UJ131, characterization, xylanase. 


\section{Pendahuluan}

Hutan mangrove memiliki peran ekologis yang besar bagi kehidupan manusia yang berfungsi mulai dari penyedia sumber makanan, bahan baku industri, mencegah banjir, mencegah erosi, hingga fungsi rekreasi (Risnandar, 2017). Aspek kehidupan biologi hutan mangrove dipengaruhi oleh produksi serasah, dekomposisi oleh mikroorganisme, pengambilan mineral oleh tumbuhan dan aktivitas-aktivitas biologi lainnya sehingga ekosistem dalam hutan mangrove menjadi seimbang (Purnobasuki, 2005).

Di sekitar hutan mangrove Margasari diketahui terdapat budidaya tambak udang. Bakteri Bacillus merupakan bakteri yang berbentuk batang dapat dijumpai di tanah dan air termasuk pada air laut (Hatmanti, 2000). Dengan demikian, maka tentu juga ada bakteri Bacillus sp. yang hidup di lokasi hutan mangrove tersebut dan berperan dalam probiotik udang seperti yang terjadi di mangrove Wonorejo (Pratiwi et al., 2013). Seperti diketahui hutan mangrove memiliki juga biodiversitas yang tinggi untuk eksplorasi mikroba penghasil enzim, salah satunya enzim xilanase. Enzim xilanase berperan dalam menghidrolisis xilan menjadi xilooligosakarida dan xilosa (Susilowati et al., 2012). Xilan banyak terdapat pada serat pakan ternak dan pakan ikan. Keberadaan mikroba tersebut dapat membantu pencernaan udang (Usman \& Rochmady, 2017). Xilanase telah diisolasi dari bermacam-macam fungi dan bakteri terutama Bacillus sp. (Breccia et al, 1998), Trichoderma sp. (Biely et al., 1998), isolat jamur CS_5, CS_7, CS_13, CS_15 \& CS_21 (Irawan et al, 2007) dan Verrucosispora sp. K2-04 dari spesies actinomycetes yang diisolasi dari sedimen hutan mangrove Kuantan, Malaysia (Omar et al., 2017).

Bacillus sp. adalah salah satu bakteri yang mampu meningkatkan daya cerna dan berpotensi sebagai probiotik (Irianto, 2003). Beberapa jenis bakteri yang terdapat dalam saluran pencernaan hewan memiliki peran penting dalam rangka meningkatkan pemanfaatan pakan dan kesehatan ikan (Watson et al., 2008). Sumber bahan organik dalam budidaya ikan dan udang sebagian besar $(90 \%)$ berasal dari pakan dan sisanya berasal dari run off (aliran permukaan) serta air tawar atau laut (Funge-Smith \& Briggs, 1998). Setiawati et al., (2013) melaporkan kandungan karbohidrat pada pakan ikan tanpa pemberian probiotik yakni 37,44 $\%$ dan mengalami penurunan menjadi $21,80 \%$ setelah pemberian probiotik.

Karbohidrat yang berupa serat kasar pada pakan tersebut dihidrolisis oleh enzim dari bakteri probiotik sehingga mikroba dan inang mendapat 168 keuntungan berupa senyawa sederhana yang diperoleh dari hasil perombakan molekul kompleks tersebut. Menurut Effendi (2002), prinsip dasar kerja probiotik adalah pemanfaatan kemampuan mikroorganisme dalam memecah polisakarida, protein dan lemak yang menyusun pakan yang diberikan karena adanya enzim-enzim khusus yang dimiliki mikroba untuk memecah ikatan tersebut.

Sebelum digunakan sebagai probiotik, Bacillus sp. UJ131 perlu dilakukan karakterisasi enzim yang dihasilkan seperti enzim xilanase. Oleh karena itu, perlu dilakukan penelitian untuk mengetahui produksi dan karakterisasi enzim xilanase isolat Bacillus sp. UJ131. sebagai kandidat probiotik.

\section{Metodologi}

Penelitian ini dilaksanakan di Laboratorium Mikrobiologi Jurusan Biologi Fakultas Matematika dan Ilmu Pengetahuan Alam Universitas Lampung dari bulan Januari sampai Maret 2018. Media utama yang digunakan dalam penelitian adalah media sea water complete (SWC) agar (bacto peptone $5 \mathrm{~g}$, ekstrak yeast $1 \mathrm{~g}$, gliserol $3 \mathrm{ml}, 15$ gram agar, air laut $750 \mathrm{ml}$, akuades $250 \mathrm{ml}$ ). Bakteri yang digunakan adalah Bacillus sp. UJ131, koleksi bakteri di Laboratorium Mikrobiologi yang diisolasi dari saluran pencernaan udang pasir kawasan hutan mangrove Margasari Lampung Timur.

\section{Bacillus sp. UJ131 Penghasil Xilanase}

Konfirmasi bakteri Bacillus sp. UJ131 penghasil xilanase dilakukan dengan cara menginokulasikan secara replika sebanyak dua cawan petri pada media SWC agar yang telah ditambahkan 0,25\% xylane beechwood. Biakan bakteri diinkubasi pada suhu ruang selama 24 jam. Setelah 24 jam, koloni yang tumbuh diwarnai dengan congo red $1 \%$ kemudian dicuci dengan larutan $\mathrm{NaCl} 10 \%$. Zona jernih yang ada di media tersebut menunjukkan aktivitas enzim xilanase. Bakteri Bacillus sp. UJ131 tersebut kemudian dibuat starter untuk produksi enzim xilanase. Bakteri Bacillus sp. UJ131 yang sudah diremajakan pada media SWC diambil 1 ose dan diinokulasikan kedalam erlenmeyer $100 \mathrm{ml}$ yang berisi $50 \mathrm{ml}$ media SWC cair. Kemudian biakan bakteri diinkubasi selama 24 jam di shaker orbital pada suhu ruang dengan $120 \mathrm{rpm}$.

\section{Penentuan Lama Produksi dan uji aktivitas enzim xilanase}

Waktu produksi optimum enzim
dilakukan dengan menggunakan inokulum


Bacillus sp. UJ131 yang sudah diinkubasi selama 24 jam pada media starter. Sebanyak 10\% media starter diinokulasikan ke dalam media SWC cair $45 \mathrm{ml}$ yang telah ditambahkan $0,25 \%$ xylane beechwood. Kemudian kultur diinkubasi pada suhu ruang selama 6 jam, 12 jam, 18 jam, 24 jam, 30 jam, dan 36 jam. Setelah diinkubasi, kultur disentrifus $7500 \mathrm{rpm}$ pada suhu $4^{\circ} \mathrm{C}$ selama 15 menit untuk mendapatkan supernatan yang merupakan ekstrak kasar enzim xilanase dari Bacillus sp. UJ131. Ekstrak kasar enzim xilanase ini kemudian diuji aktivitasnya. Waktu inkubasi dengan aktivitas enzim tertinggi akan digunakan untuk produksi enzim selanjutnya.

Aktivitas xilanase diukur dengan mendeteksi gula pereduksi yang terbentuk menggunakan metode Miller (1959). Ekstrak kasar enzim sebanyak $0,5 \mathrm{ml}$ ditambahkan dengan $0,5 \mathrm{ml}$ buffer fosfat $\mathrm{pH} 7$ dengan konsentrasi $0,25 \%$ xylane beechwood sebagai substrat. Kemudian sebanyak $1 \mathrm{ml}$ campuran tersebut (enzim + substrat) diinkubasi pada suhu ruang selama 30 menit. Setelah diinkubasi ditambahkan $1 \mathrm{ml}$ DNS lalu dipanaskan dalam air mendidih selama 15 menit. Setelah itu, didinginkan selama 20 menit. Larutan diukur dengan spektrofotometer pada panjang gelombang $575 \mathrm{~nm}$. Xilosa digunakan sebagai standar untuk penghitungan aktivitas xilanase. Penentuan gula standar xilosa ditentukan dengan metode Bernfeld (1955). Aktifitas enzim xilanase dihitung dalam satuan International Unit (IU). Satu unit merupakan jumlah enzim yang dibutuhkan untuk memecah 1 $\mu$ mol xilan menjadi xilosa yang dibebaskan per menit pada kondisi pengujian.

\section{Karakterisasi Enzim Xilanase}

Karakterisasi enzim dilakukan dengan menguji pengaruh suhu, $\mathrm{pH}$, dan ion logam terhadap aktivitas enzim xilanase. Pada proses pengujian pengaruh suhu, enzim diuji aktivitasnya pada berbagai macam suhu. Reaksi enzim diinkubasi dengan variasi suhu yang digunakan yaitu $30,40,50,60,70$, dan $80^{\circ} \mathrm{C}$ dengan waktu inkubasi 30 menit.

Pada proses pengujian pengaruh $\mathrm{pH}$, enzim diuji aktivitasnya dengan beberapa jenis buffer dengan $\mathrm{pH}$ tertentu. Buffer yang digunakan pada uji ini antara lain sitrat $\mathrm{pH} 4, \mathrm{pH} 5, \mathrm{pH} 6$; posfat $\mathrm{pH} 7$; tris $\mathrm{pH} 8, \mathrm{pH} 9$; glycan- $\mathrm{NaOH} \mathrm{pH} 10$, $\mathrm{pH} 11$, dan $\mathrm{pH}$ 12. $\mathrm{pH}$ buffer yang menghasilkan aktivitas enzim tertinggi menunjukkan $\mathrm{pH}$ optimum, dengan menggunakan jenis buffer dan $\mathrm{pH}$ yang sudah ditentukan kemudian diinkubasi pada suhu optimum.

Dalam reaksi enzim, ada senyawa yang dapat mempercepat atau menghambat aktivitas enzim. Senyawa tersebut dapat berupa logam. Senyawa penghambat yang digunakan adalah asam etilen diamintetraasetat (EDTA). Pengaruh ion logam pada aktivitas enzim diuji dengan mereaksikan enzim dengan $\mathrm{MnSO}_{4}, \mathrm{CaCl}_{2}$, $\mathrm{CuSO}_{4}, \quad \mathrm{MgSO}_{4}$, dan $\mathrm{FeCl}_{3}$ masing-masing konsentrasi $1 \mathrm{mM}$ dan $5 \mathrm{mM}$ (Sumardi et al., 2018).

\section{Penentuan Nilai $K_{m}$ dan $V_{\text {max }}$}

Penentuan $\mathrm{V}_{\max }$ dan $\mathrm{K}_{\mathrm{m}}$ ditentukan dengan cara menguji aktivitas xilanase pada suhu dan $\mathrm{pH}$ optimumnya dengan menggunakan variasi konsentrasi substrat xylan beechwood sebagai berikut: $0 ; 0.5 ; 0,75 ; 1 ; 1,25 ; 1,5 ; 1,75$ dan $2 \%$ dengan waktu inkubasi selama 30 menit. Nilai aktivitas xilanase yang diperoleh kemudian digunakan untuk membuat kurva hubungan antara konsentrasi xylan beechwood dan aktivitas spesifik enzim. Kemudian hasilnya ditransformasi dan dimasukkan ke dalam persamaan linear Lineweaver-Burk. Dari hasil grafik yang diperoleh selanjutnya nilai $\mathrm{V}_{\max }$ dan $\mathrm{K}_{\mathrm{m}}$ dapat diketahui. Nilai $\mathrm{V}_{\max }$ menunjukkan tingkat kejenuhan enzim oleh substrat sedangkan $K_{m}$ menunjukkan efisiensi katalis dari enzim yang didefinisikan sebagai konsentrasi substrat tertentu pada saat kecepatan katalitik enzim mencapai setengah kecepatan maksimumnya.

\section{Hasil}

\section{Uji Seleksi Bacillus sp UJ131 sebagai Penghasil Xilanase}

Isolat Bacillus sp. UJ131 ini mampu menghasilkan xilanase yang ditunjukkan dengan adanya zona jernih di sekitar koloni bakteri yang dipertegas dengan menggunakan pewarna Congo red dicuci dengan larutan $\mathrm{NaCl} 10 \%$ (Gambar 1).

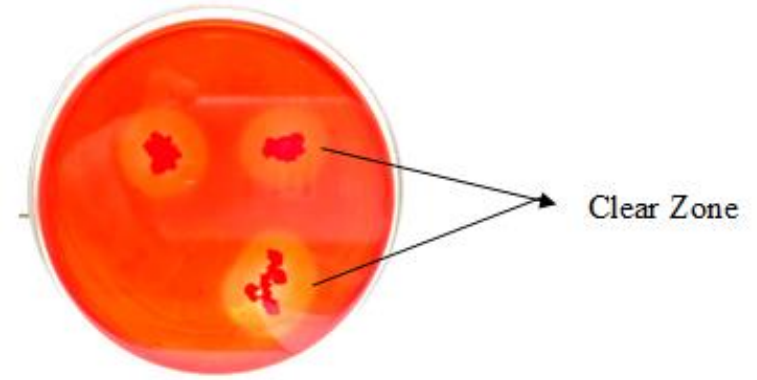

Gambar 1. Uji seleksi aktivitas xilanase terhadap 3 koloni Bacillus sp. UJ131.

Figure 1. Selective test of xylanse activity on colonies of Bacillus sp. UJ131.

\section{Penentuan Waktu Produksi Enzim Xilanase}

Berdasarkan hasil penelitian diperoleh waktu produksi optimum enzim xilanase adalah 18 jam. Pada waktu produksi 18 jam diperoleh 
aktivitas enzim xilanase tertinggi dibandingkan waktu produksi lain yang diuji (Gambar 2).

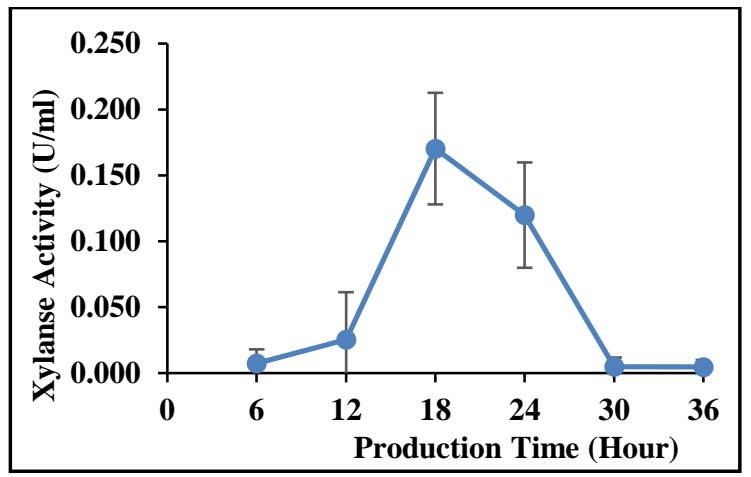

Gambar 2. Pengaruh waktu produksi xilanase.

Figure 2. Effect of xylanase production period.

Aktivitas enzim pada penentuan waktu optimum produksi 6 jam hingga 18 jam terjadi peningkatan, pada jam ke-6 aktivitas xilanase sebesar $0,007 \mathrm{U} / \mathrm{ml}$ dan mengalami kenaikan pada jam ke-12 sebesar 0,025 U/ml. Kemudian pada jam ke-18 tercapai titik maksimum aktivitas xilanase yaitu sebesar $0,18 \mathrm{U} / \mathrm{ml}$. Selanjutnya memasuki waktu produksi pada jam ke 24, 30 dan 36 , aktifitas enzim xilanase mengalami penurunan dari aktivitas enzim sebesar $0,12 \mathrm{U} / \mathrm{ml}$ menjadi $0,005 \mathrm{U} / \mathrm{ml}$ pada $30 \mathrm{jam}$ dan $36 \mathrm{jam}$.

\section{Karakterisasi Enzim Xilanase}

Pada penelitian ini, isolat bakteri Bacillus sp. UJ131 diketahui memiliki aktivitas tertinggi pada suhu $70^{\circ} \mathrm{C}$ dengan aktivitas relatif xilanase sebesar 100\% (Gambar 3).

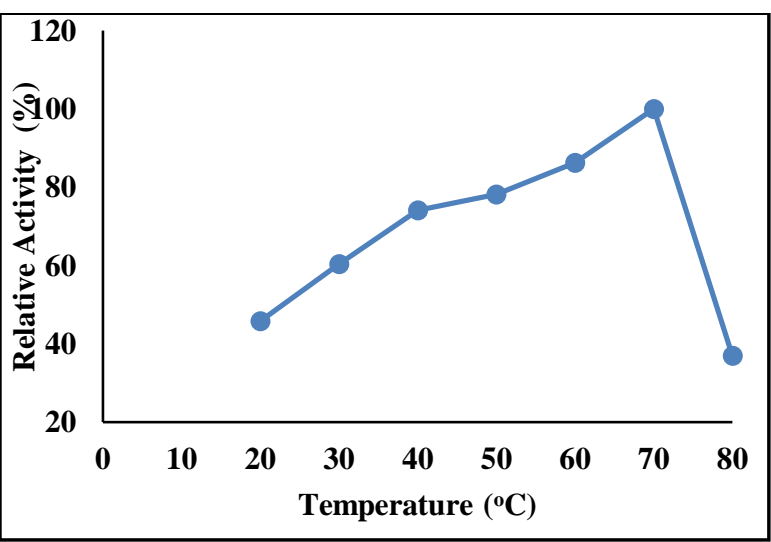

Gambar 3. Pengaruh perbedaan suhu pada aktivitas xilanase.

Figure 3. Effect of temperature different on xylanase activity.

Aktivitas enzim pada penentuan suhu optimum terjadi peningkatan secara signifikan dari suhu $20^{\circ} \mathrm{C}$ hingga $70^{\circ} \mathrm{C}$. Aktivitas relatif xilanase pada suhu $20^{\circ} \mathrm{C}$ hingga $70^{\circ} \mathrm{C}$ dalam interval 10 berturut-turut sebesar 46, 60, 74, 78, 86, dan $100 \%$. Aktivitas enzim mengalami penurunan pada suhu $80^{\circ} \mathrm{C}$ dengan aktivitas relatif xilanase sebesar $37 \%$.

\section{Pengaruh pH dan Ion Logam Terhadap Aktivitas Enzim Xilanase}

Aktivitas enzim tertinggi terjadi pada $\mathrm{pH}$ 6, pada $\mathrm{pH} 4$ aktivitas enzim tidak terlalu tinggi, kemudian pada $\mathrm{pH} 5$ terjadi kenaikan yang puncaknya terdapat pada $\mathrm{pH} 6$ dan kemudian menurun pada $\mathrm{pH} 7$ hingga $\mathrm{pH} 11$. Pada $\mathrm{pH} 12$ terdapat aktivitas xilanase dengan relatif sebesar $3 \%$.

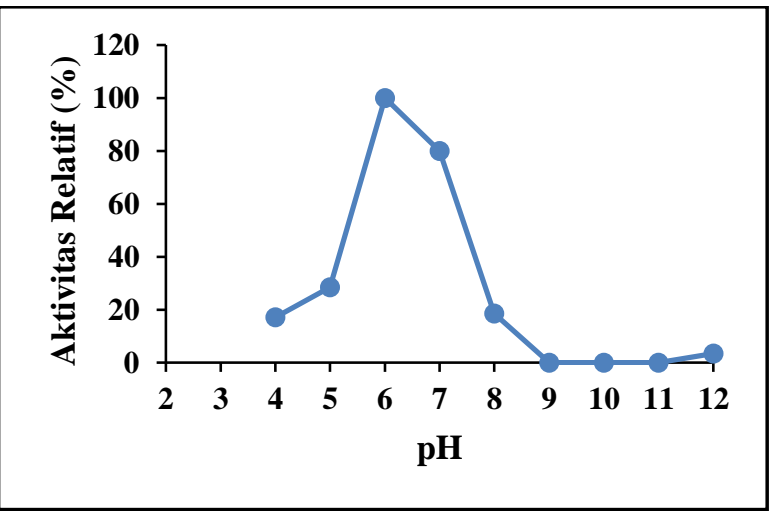

Gambar 4. Pengaruh perbedaan $\mathrm{pH}$ pada aktivitas xilanase.

Figure 4. Effect of $\mathrm{pH}$ different on xylanase activity.

Aktivitas tertinggi pada $\mathrm{pH} 6$ menghasilkan aktivitas relatif xilanase $100 \%$ kemudian pada $\mathrm{pH} 7$ menurun menjadi $80 \%$ dan pH 8 sebesar $18 \%$ lalu menurun pada $\mathrm{pH} 9,10$ dan 11 dengan tidak adanya aktivitas xilanase, sedangkan untuk pH 4 dan 5 aktivitas relatif xilanase berturut-turut sebesar $17 \%$ dan $28 \%$.

Aktivitas xilanase dapat ditingkatkan oleh ion logam $\mathrm{Mn}^{2+}$ dan $\mathrm{Ca}^{2+}$ pada konsetrasi $1 \mathrm{mM}$. Ion $\mathrm{Fe}^{3+}, \mathrm{Cu}^{4+}$ dan $\mathrm{Mg}^{2+}$ pada konsentrasi $5 \mathrm{mM}$ memberikan pengaruh terhadap penurunan aktivitas enzim xilanase.

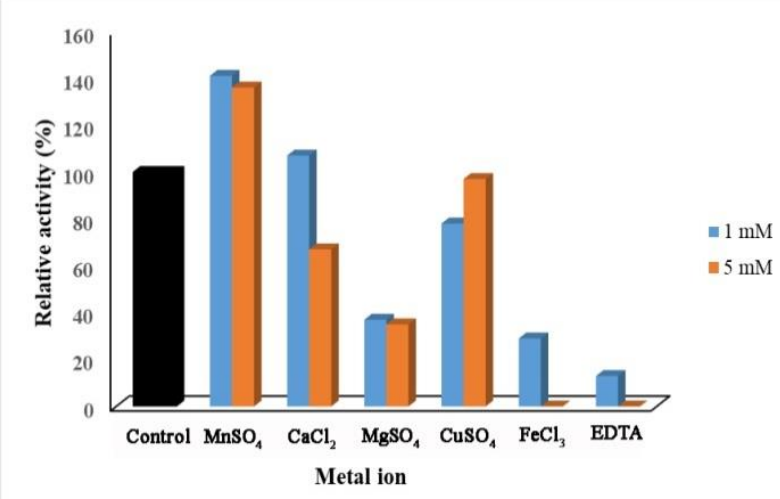

Gambar 5. Pengaruh ion logam terhadap aktivitas enzim xilanase.

Figure 5. The influence of metal ions on xylanase enzyme activity. 
Nilai $K_{m}$ dan $V_{\max }$

Nilai $\mathrm{V}_{\max }$ dan $\mathrm{K}_{\mathrm{m}}$ ditentukan dengan cara mengukur kecepatan awal dan aktivitas xilanase pada kondisi optimumnya ( $\mathrm{pH} 6$ dan suhu $70^{\circ} \mathrm{C}$ ) pada variasi konsentrasi substrat 0,$50 ; 0,75 ; 1,00$; 1,$25 ; 1,5 ;$ dan $2 \%$.

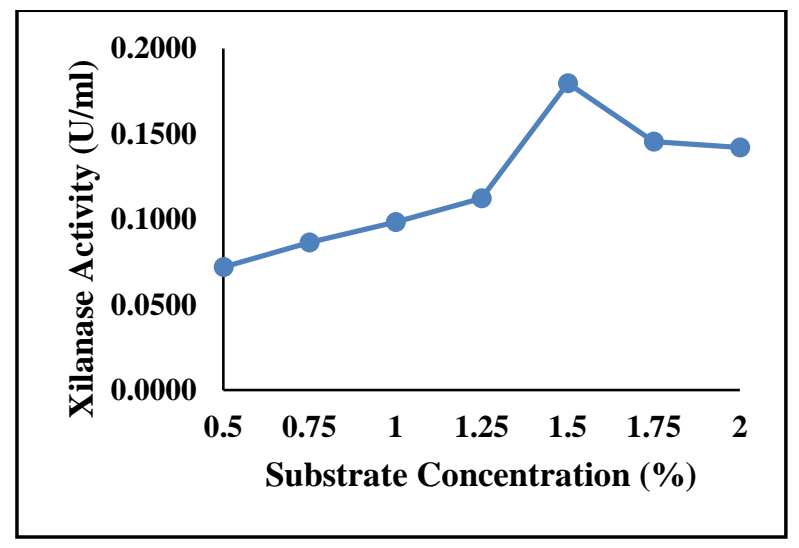

Gambar 6. Hubungan konsentrasi substrat dengan aktivitas enzim.

Figure 6. Correlation of substrate concentration with enzyme activity.

Gambar 6 menunjukkan bahwa konsentrasi substrat optimum pada substrat xilan $1,5 \%$ dengan aktivitas xilanase sebesar $0,18 \mathrm{U} / \mathrm{ml}$. Berdasarkan Gambar 7 diperoleh persamaan linear $\mathrm{y}=5,2058 \mathrm{x}+4,0312$, sehingga nilai $\mathrm{V}_{\max }$ sebesar 0,25 U/ml dan $\mathrm{K}_{\mathrm{m}}$ sebesar $1,30 \mathrm{mg} / \mathrm{ml}$.

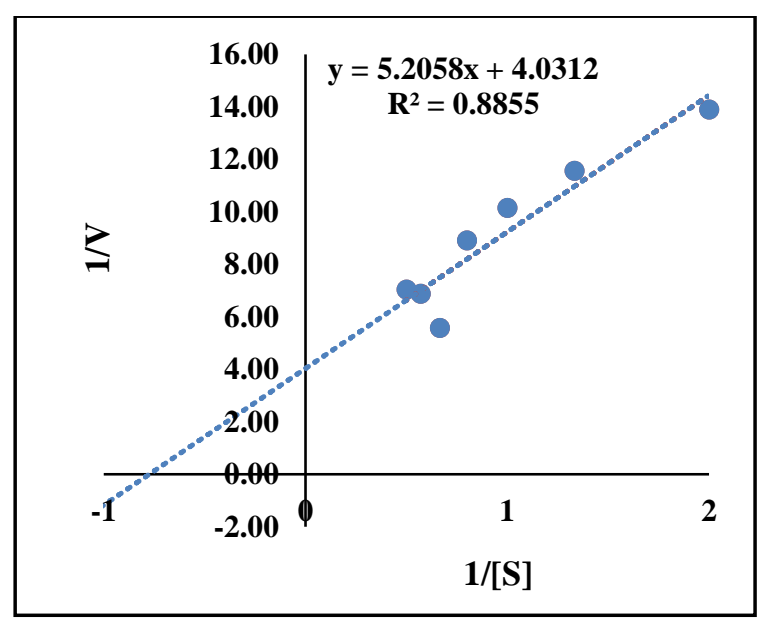

Gambar 7. Persamaan Linear Lineweaver-Burk.

Figure 7. Linear Lineweaver-Burk Equations.

1/[S]: 1/[ xylane beechwood]

$1 / \mathrm{V}: 1 /$ xylanase activity

\section{Pembahasan}

Pada pengujian aktivitas xilanase secara kualitatif media ditambahkan 0,25\% xylane beechwood menunjukan adanya zona jernih (Gambar 1) yang diakibatkan oleh proses degradasi xilan oleh xilanase yang dihasilkan oleh bakteri Bacillus sp. UJ131. Menurut Jo et al., (2011) medium padat jika digenangi oleh Congo red akan menghasilkan zona jernih karena Congo red tidak dapat berikatan dengan xilan di medium tersebut. Ketiadaan xilan disekeliling koloni bakteri tersebut menandakan tidak adanya ikatan $\beta-1,4$ glikosidik karena telah terhidrolisis oleh enzim xilanase.

Aktivitas enzim xilanase diuji dengan metode DNS. Reaksi antara gula reduksi dengan DNS merupakan reaksi redoks pada gugus aldehid gula dan teroksidasi menjadi gugus karboksil. Sementara itu, DNS sebagai oksidator akan tereduksi membentuk asam 3-amino dan 5nitrosalisilat. Reaksi ini berlangsung dalam suasana basa dan suhu tinggi sekitar $90-100^{\circ} \mathrm{C}$. Bila terdapat gula reduksi pada sampel, maka larutan DNS yang awalnya berwarna kuning akan bereaksi dengan gula reduksi sehingga menimbulkan warna jingga kemerahan (Kusmiati \& Agustini, 2010).

Berdasarkan penelitian ini, waktu produksi optimum enzim xilanase adalah 18 jam. Pada waktu produksi 18 jam diperoleh aktivitas enzim xilanase tertinggi dibandingkan waktu produksi lain yang diuji (Gambar 2). Pertumbuhan mikroorganisme memiliki beberapa fase yaitu fase lag (fase pertumbuhan lambat/adaptasi), fase eksponensial (fase pertumbuhan cepat), dan fase kematian (Al-Hakim, 2001). Setelah 18 jam waktu produksi Bacillus sp. UJ131 memasuki fase eksponensial dan memanfaatkan sumber nutrisi yang sangat tinggi dalam media. Setelah sumber nutrisi habis, bakteri memasuki fase kematian yang ditunjukkan dengan menurunnya jumlah sel bakteri. Hasil ini sesuai dengan penelitian Erika et al., (2016) yang menunjukkan aktivitas xilanase meningkat mulai jam ke-6 sampai jam ke-24 dan mengalami penurunan pada jam ke-30.

Suhu sangat memengaruhi kerja suatu enzim. Menurut Baehaki (2011), pada umumnya setiap enzim memiliki aktivitas maksimum pada suhu tertentu, aktivitas enzim akan semakin meningkat sejalan dengan bertambahnya suhu sampai suhu optimum tercapai. Pada penelitian ini, isolat bakteri Bacillus sp. UJ131 diketahui memiliki aktivitas tertinggi pada suhu $70^{\circ} \mathrm{C}$ (Gambar 3). Beberapa penelitian juga memperoleh xilanase dengan suhu $70^{\circ} \mathrm{C}$ diantaranya Bacillus sp. dari saluran pencernaan ayam (Nabilasani, 2015), Actinobacter baumanni asal air laut manado (Fawzya et al., 2013), Geobacillus sp. MT-1 asal laut dalam Samudera Pasifik (Wu et al., 2006), Bacillus sp. NCIM 59 (Kulkarni \& Rao, 1996), dan Bacillus halodurans S7 (Mamo et al., 2006). Enzim ini tergolong 
termoenzim, karena memiliki aktivitas optimum di dalam kisaran suhu $45-80^{\circ} \mathrm{C}$ (Nam, 2004).

Kemampuan aktivitas enzim termofilik pada suhu tinggi disebabkan oleh banyaknya ikatan disulfida pada struktur protein enzim. Ikatan disulfida (-S-S- atau sistin) merupakan ikatan kovalen yang sangat kuat sehingga dibutuhkan suhu yang sangat tinggi untuk mengurai ikatannya. Ikatan disulfida akan menstabilkan struktur sekunder dan struktur tersier protein enzim sehingga protein termoenzim tetap stabil pada suhu tinggi dan tidak kehilangan kemampuan katalisnya. Selain itu, peningkatan suhu sampai pada suhu tertentu akan meningkatkan jumlah tumbukan antara sisi aktif enzim dengan substrat, sehingga kecepatan reaksi dan aktivitas enzim meningkat. Penurunan aktivitas enzim pada suhu yang lebih tinggi disebabkan oleh denaturasi pada suhu tinggi yang mengakibatkan putusnya ikatan hidrogen, ikatan hidrofobik dan ikatan elektrostatik pada enzim, sehingga merusak struktur lipatan protein enzim (Murray et al., 2003).

Selain suhu, $\mathrm{pH}$ juga memengaruhi jalannya aktivitas enzim. Pada penelitian ini tampak bahwa xilanase bekerja optimum pada $\mathrm{pH}$ 6, karena sifat ionik gugus karboksil dan gugus amino mudah dipengaruhi oleh $\mathrm{pH}$. Perubahan $\mathrm{pH}$ atau $\mathrm{pH}$ yang tidak sesuai akan menyebabkan daerah katalitik dan konformasi enzim berubah (Girindra, 1993; Meryandini et al., 2009). Enzim merupakan suatu protein yang memiliki aktivitas biokimiawi sebagai katalis suatu reaksi. Karena merupakan suatu protein, enzim ini sangat rentan terhadap kondisi lingkungan. Adanya perubahan $\mathrm{pH}$ lingkungan akan mengakibatkan aktivitas enzim ikut mengalami perubahan meskipun masih banyak juga hal lain yang dapat mempengaruhi aktivitas enzim misalnya temperatur atau komposisi media (Sholihati et al, 2015).

Menurunnya aktivitas enzim karena perubahan $\mathrm{pH}$ larutan yang tidak terlalu besar (sedikit dibawah atau diatas $\mathrm{pH}$ optimalnya) disebabkan oleh berubahnya keadaan ion enzim dan seringkali juga keadaan ion substrat. Perubahan kondisi ion enzim dapat terjadi pada residu asam amino yang berfungsi sebagai katalitik yang dapat mengikat substrat maupun residu asam amino. Hal ini berfungsi untuk mempertahankan struktur tersier dan kwartener enzim yang aktif. Aktivitas enzim yang mengalami penurunan tersebut dapat dipulihkan kembali dengan merubah kondisi reaksi enzimatis pada $\mathrm{pH}$ optimalnya. Pada $\mathrm{pH}$ tertentu perubahan muatan ion pada rantai samping yang dapat terionisasi dari residu asam amino enzim menjadi terlalu besar sehingga mengakibatkan terjadinya 172 denaturasi enzim yang disertai dengan hilangnya aktivitas katalitik enzim. Selain itu, perubahan struktur tersier menyebabkan kelompok hidrofobik kontak dengan air sehingga solubilitas enzim menjadi berkurang. Berkurangnya solubilitas enzim dapat mengakibatkan turunnya aktivitas enzim secara bertahap (Palmer, 1981; Harper et al,. 1984; Meryandini et al., 2008).

Hasil penelitian menunjukkan bahwa ion logam juga memengaruhi aktivitas enzim xilanase. Ion logam $\mathrm{Mn}^{2+}$ dan $\mathrm{Ca}^{2+}$ pada konsetrasi $1 \mathrm{mM}$ dapat meningkatkan aktivitas xilanase, sedangkan ion $\mathrm{Fe}^{3+}, \mathrm{Cu}^{2+}$, dan $\mathrm{Mg}^{2+}$ pada konsentrasi $5 \mathrm{mM}$ memberikan pengaruh terhadap penurunan aktivitas enzim xilanase. Menurut penelitian Fawzya et al., (2013), ion $\mathrm{Fe}^{3+}, \mathrm{Ca}^{2+}$, dan $\mathrm{Mg}^{2+}$ pada konsentrasi $5 \mathrm{mM}$ memberikan pengaruh terhadap penurunan aktivitas enzim xilanase A. baumannii yang berasal dari air laut Manado. Penghambatan aktivitas enzim akibat penambahan ion logam diduga karena ion logam tersebut memengaruhi sisi aktif enzim xilanase sehingga struktur tiga dimensi enzim tidak sesuai dengan substrat. Hal ini berakibat pada ketidakmampuan substrat berikatan dengan sisi aktif enzim, sehingga reaksi berjalan lambat. Penghambatan aktivitas xilanase oleh ion $\mathrm{Fe}^{3+}$ juga dilaporkan oleh Menon et al., (2010) pada xilanase Bacillus pumilus strain GESF-1.

Penentuan laju reaksi maksimum $\left(\mathrm{V}_{\max }\right)$ dan konstanta Michaelis-Menten $\left(\mathrm{K}_{\mathrm{m}}\right)$ merupakan hal penting yang harus dilakukan untuk mengetahui karakteristik enzim. Berdasarkan teori kinetika, semakin tinggi konsentrasi substrat maka semakin tinggi pula energi dan frekuensi benturan antara molekul enzim dan substrat (Gultom, 2001). Dengan demikian maka semakin banyak enzim xilanase yang membentuk kompleks xilanase - xilan yang selanjutnya diubah menjadi produk berupa xilosa. Hal ini dapat ditunjukkan pada Gambar 6 bahwa dengan meningkatnya konsentrasi substrat maka meningkat pula aktivitas enzim yang dihasilkan. Meskipun demikian, peningkatan aktivitas enzim akan berhenti ketika enzim sudah jenuh dengan substrat karena jumlah molar substrat sudah melampaui jumlah molar enzim setelah titik batas maksimum $\left(\mathrm{V}_{\max }\right)$ dari reaksi enzimatis (Saropah et al., 2012).

Berdasarkan Gambar 7 diperoleh persamaan linear $y=5,2058 x+4,0312$, diperoleh nilai $1 / \mathrm{V}_{\max }=4,0312$ dan nilai $\mathrm{Km} / \mathrm{V}_{\max }=$ 5,2058 sehingga nilai $\mathrm{V}_{\max }$ sebesar $0,25(\mu \mathrm{mol}$ xilosa/menit/ml) dan $\mathrm{K}_{\mathrm{m}}$ sebesar $1,30(\mathrm{mg} / \mathrm{ml})$. Hasil penelitian menunjukkan bahwa pada kecepatan reaksi maksimalnya, xilanase dari Bacillus sp. UJ131 dapat menghasilkan 1,30 $\mu \mathrm{M}$ xilosa per menit. Nilai $\mathrm{V}_{\max }$ tersebut menunjukkan 
kecepatan maksimum enzim xilanase dalam memecah substrat xilan menjadi xilosa. Menurut Saropah et al., (2012) semakin kecil kecenderungan substrat dan enzim berdisosiasi maka semakin besar afinitas enzim terhadap substratsehingga kompleks ES sangat mantap. Apabila nilai $\mathrm{K}_{\mathrm{m}}$ besar berarti enzim mempunyai afinitas rendah terhadap substrat, sehingga terjadi kesetimbangan reaksi kearah $\mathrm{E}+\mathrm{S}$.

Pada penelitian lain yang dilakukan oleh Meryandini et al., (2008), dinyatakan bahwa enzim xylanase dari Streptomyces sp. dihasilkan $\mathrm{V}_{\max }=0,18 \mathrm{U} / \mathrm{ml}$ dan nilai $\mathrm{K}_{\mathrm{m}}=0,101(\mathrm{mg} / \mathrm{ml})$. Pada kecepatan reaksi maksimal, xilanase dari Streptomyces sp. SKK1-8 dapat menghasilkan $0,101 \mu \mathrm{M}$ xilosa per menit. Apabila dibandingkan dengan kecepatan reaksi maksimalnya, ternyata xilanase dari Bacillus sp. UJ131 masih lebih tinggi yakni sebesar $1,30 \mu \mathrm{M}$ xilosa per menit. Dengan demikian maka xilanase dari Bacillus sp. UJ131 lebih efektif.

\section{Kesimpulan}

Isolat Bacillus sp. UJ131 yang berasal dari saluran pencernaan udang pasir kawasan hutan mangrove desa Margasari Lampung Timur dapat menghasilkan enzim xilanase. Enzim tersebut berperan dalam menentukan potensi Bacillus sp. UJ131 sebagai kandidat probiotik udang laut. Enzim tersebut dapat membantu pencernaan udang laut. Pada kondisi laboratorium, Bacillus sp. UJ131 menghasilkan enzim xilanase di waktu produksi optimum 18 jam dengan aktifitas $0,18 \mathrm{U} / \mathrm{ml}$. Enzim xylanase yang dihasilkan aktif pada $\mathrm{pH} 6$ dan suhu $70^{\circ} \mathrm{C}$. Penambahan ion $\mathrm{Mn}^{2+}$ dan $\mathrm{Ca}^{2+}$ dapat meningkatkan aktivitas enzim, sedangkan ion $\mathrm{Fe}^{3+}, \mathrm{Cu}^{2+}$, dan $\mathrm{Mg}^{2+}$ menurunkan aktivitas enzim xilanase. Hasil kecepatan reaksi maksimalnya $\left(\mathrm{V}_{\text {maks }}=0,25 \mathrm{U} / \mathrm{ml}\right)$, enzim tersebut dapat menghasilkan $1,30 \mu \mathrm{M}$ xilosa per menit.

\section{Daftar Pustaka}

Al-Hakim, C. (2001). Isolasi dan seleksi bakteri unggul penghasil enzim xylanase dengan penentuan suhu dan ph optimum pertumbuhannya (Skripsi). Institut Pertanian Bogor, Bogor.

Baehaki, A., Rinti, \& Budiman, A. (2011). Isolasi dan karakterisasi protease dari bakteri Tanah Rawa Indralaya, Sumatera Selatan. Jurnal Teknologi dan Industri Pangan, 22(1), 1016.

Bernfeld, P. (1955). Amylase $\alpha$ and $\beta$. Methods in Enzymology, 1, 149-158. http://dx.doi.org/10.1016/0076-

6879(55)01021-5

Breccia, J.D, Torto, N. Gorton, L.,Sineriz, F. \& Kaul, R.H. (1998). Specifity and mode of action of thermostable xylanase from Bacillus amyloliquefaciens on-line monitoring of hydrolysis products. Applied Biochemistry and Biotechnology, 69(1), 3139.

Biely, P \& Tenkanen, N. (1998). Enzimology of hemicellulose degradation. In G.E Harman \& C.P. Kubicek (Eds). Trichoderma and Gliocladium Vol. 2. enzymes, biological control and commercial application (pp. 2547). London, U.K: Taylor \& Francis Ltd.

Erika, Agustrina, R., Sumardi, \& Mulyono. (2016). Optimasi media produksi xilanase dari Bacillus sp. Jurnal Selulosa, 6(1), 1926.

Effendi, I. (2002). Probiotics for marine organism disease protection. Pekanbaru, Indonesia: Fakultas Perikanan dan Ilmu Kelautan Universitas Riau.

Fawzya, Y.N., Rani, E.P., Wibowo, M., Ifah, M., \& Gintung, P. (2013). Produksi dan karakterisasi xilanase dari isolat bakteri $\mathrm{M}$ 13.2A asal air laut Manado. JPB Kelautan dan Perikanan, 8(1), 55-64.

Funge-Smith, S., \& Briggs, M.R.P. (1998). Nutrient budgets in intensive shrimp ponds: Implication for sustainability. Aquaculture, 164(1), 117-133.

Girindra, A. (1993). Biokimia 1. Jakarta, Indonesia: PT. Gramedia.

Gultom, T. (2001). Biokimia struktur dan fungsi. Yogyakarta, Indonesia: UNY Press.

Harper, H.A., Rodwel, V.W., \& Mayer, P.A. (1984). Review of physiological chemistry. California, U.S: Lange Medical Publication.

Hatmanti, A. (2000). Pengenalan Bacillus spp. Oseana, 25(1), 31-41.

Irawan, B., Sumardi, Aspita, L., Hafnirsa, P., \& Tusi, T. (2007). Decomposition properties (weight loss, xylanase and cellulase activities) of soil fungi based on pure culture decomposition test. Jurnal Sains MIPA, 13(1), 11-16.

Irianto, A. (2003). Probiotik akuakultur. Yogyakarta, Indonesia: Gadjah Mada University Press.

Jo, W.S., Park, H.N., Cho, D.H., Yoo, Y.B., \& Park, S.C. (2011). Optimal media conditions for the detection of extracellular celluase activity in Ganoderma neo-japonicum. Journal of Mycobiologi, 39(2), 129-132.

Kulkarni, N. \& M. Rao. 1996. Application of xylanase from alkaliphilic thermophilic 
Bacillus sp. NCIM 59 in biobleaching of bagasse pulp. Journal of Biotechnology, $51(2)$, 167-173.

https://doi.org/10.1016/01681656(96)01616-1

Kusmiati \& Agustini, N.W.S. (2010). Pemanfaatan limbah onggok untuk produksi asam sitrat dengan penambahan mineral $\mathrm{Fe}$ dan $\mathrm{Mg}$ pada substrat menggunakan kapang Trichoderma sp. dan Aspergillus niger. Seminar Nasional Biologi (hal. 856-866). Fakultas iologi UGM, Yogyakarta, Indonesia.

Mamo, G., Kaul, R.H., \& Mattiasson, B. (2006). A thermostable alkaline active endo- $\beta-1-4$ xylanase from Bacillus halodurans S7: purification and characterization. Enzyme and Microbial Technology, 39(7), 14921498. https://doi.org/10.1016/j.enzmictec.2006.03. $\underline{040}$

Menon, G., Mody, K., Keshri, J., \& Jha, B. (2010). Isolation, purification and characterization of haloalkaline xilanase from a marine Bacillus pumilus strain, GESF-1. Biotechnology and Bioprocess Engineering, 15(6), 998-1005.

Meryandini, A., Widhyastuti, N., \& Lestari, Y. (2008). Pemurnian dan karakterisasi xilanase Streptomyces sp. SKK1-8. Makara Journal of Science, 12(2), 55-60.

Meryandini, A., Wahyu, W., Besty, M., Titi, C.S., Nisa, R., \& Hasrul, S. (2009). Isolasi bakteri selulolitik dan karakterisasi enzimnya. Makara Journal of Science, 13(1), 33-38

Miller, G.L. (1959). Use of dinitrosalicylacid reagen for determination of reducing sugar. Analytical Chemistry, 31(3), 426-428.

Murray, R.K., Granner, D.K., Mayes, P.A., \& Rodwell, V.W. (2003). Biokimia Harper. Terj. Harper's biochemistry. Jakarta, Indonesia: Penerbit buku kedokteran EGC.

Nabilasani, G.C. (2015). Karakterisasi enzim xilanase dari Bacillus sp. (Skripsi). Universitas Lampung, Lampung.

Nam, E.S. (2004). $\beta$-galactosidase gene of Thermus thermophulus KNOUC11 isolated from hot springs of a volcanie area in New Zealand: identification of the bacteria cloning and expression of the gene in Escherchia coli. Asian-Aus Journal Animal Science, 17(11), 1591-1598. DOI: https://doi.org/10.5713/ajas.2004.1591

Omar, S.M., Norsyafawati, M.F., Nurfathiah, A.M., \& Zaima, A.Z.A. (2017). Verrucosispora sp. K2-04, potential xylanase producer from Kuantan Mangrove Forest sediment. International Journal of Food Engineering, 3(2), 165-168.

Palmer, T . (1981). Understanding enzymes. England: Ellis Horwood Ltd.

Pratiwi, I., Kusdarwati, R., \& Tjahjaningsih, W. (2013). Eksplorasi bakteri kandidat probiotik di lumpur Hutan Mangrove Wonorejo. Jurnal Ilmiah Perikanan dan Kelautan, 5(2), 187-192.

Purnobasuki, H. (2005). Tinjauan perspektif hutan mangrove. Surabaya, Indonesia: Airlangga University Press.

Risnandar, C. (23 Desember 2017). Hutan mangrove [tulisan blog]. Diambil dari https://jurnalbumi.com/hutan_mangrove/

Saropah, D.A., Akyunul, J., \& Anik, M. (2012). Kinetika reaksi enzimatis ekstrak kasar enzim selulase bakteri selulolitik hasil isolasi dari bekatul. Alchemy Journal of Chemistry, 2(1): 34-45.

Setiawati, J.E., Tarsim, Adiputra, Y.T., \& Hudaidah, S. (2013). Pengaruh penambahan probiotik pada pakan dengan dosis berbeda terhadap pertumbuhan, kelulushidupan, efisiensi pakan dan retensi protein ikan patin (Pangasius hypophthalmus). E-Jurnal Rekayasa dan Teknologi Budidaya Perairan, 1(2), 151-162.

Sholihati, A.M., Baharuddin, M., \& Santi. (2015). Produksi dan uji aktivitas enzim selulase dari bakteri Bacillus subtilis. Al Kimia, 3(2), 78-90.

Usman, A., \& Rochmady. (2017). Pertumbuhan dan kelangsungan hidup pasca larva udang windu (Penaeus monodon Fabr.) melalui pemberian probiotik dengan dosis berbeda. Akuatikisle: Jurnal Akuakultur, Pesisir dan Pulau-Pulau Kecil. 1(1), 19-26. URL: https://ejournal.stipwunaraha.ac.id/index.p hp/ISLE.

DOI:

https://dx.doi.org/10.29239/j.akuatikisle.1. $1.19-26$

Watson, A.K., Kaspar, H., Lategan, M.J., \& Gibson, L. (2008). Probiotics in Aquaculture: The need, principles and mechanisms of action and screening processes. Aquaculture, 274(1), 1-14.

Wu, S., Liu, B., \& Zhang, X. (2006). Characterization of a recombinant thermostable xylanase from deep-sea thermophilic Geobacillus sp. MT-1 in East Pacific. Applied Microbiology and Biotechnology, 72(6), 1210-1216 